\title{
Prinsip Dasar Pendidikan Karakter Islam Dalam Keluarga pada Cerpen Rantai Kenangan Karya Adz Dzahabi
}

\author{
Eka Nova Ali Vardani \\ Pendidikan Bahasa dan Sastra Indonesia Universitas Muhammadiyah Jember \\ nova@unmuhjember.ac.id
}

DOI: http://dx.doi.org/10.32528/bb.v5i1.2777

Diterima: 13-01-2020

Diterbitkan: 29-02-2020

\begin{abstract}
ABSTRAK
Pendidikan karakter adalah suatu proses pembelajaran yang mengajarakan nilai-nilai kehidupan bagi manusia untuk menjadi manusia yang memiliki pribadi yang berakhlak baik. Semua proses pendidikan karakter harus direncanakan, dilaksanakan, dan dievaluasi dengan baik yang didukung dengan pemahaman (ilmu) dan pengalaman yang benar. Penelitian ini difokuskan pada membina karakter dengan orang tua, meliputi (1) mengikuti keinginan dan saran kedua orang tua dalam berbagai aspek kehidupan selama tidak bertentangan dengan ajaran Islam, (2) menghormati dan memuliakan kedua orang tua serta berterima kasih atas kasih sayang dan jasa-jasa mereka, dan (3) membantu kedua orang tua secara fisik dan material. Penelitian ini merupakan penelitian kajian pustaka. Peneliti bertindak sebagai instrumen utama. Adapun prosedur penelitian ini terdiri dari tiga tahap, yaitu: tahap perencanaan, tahap pelaksanaan, dan tahap penyelesaian. Membina karakter dalam keluarga merupakan suatu hal yang tidak mudah dan tidaklah mungkin untuk tidak dilaksanakan. Bersikap baik kepada kedua orang tua merupakan amalan yang paling utama. Bagi seorang anak pada hakikatnya segala perintah kedua orang tua harus di patuhi, terkecuali apabila perintah tersebut dilakukan dengan menimbulkan kesyirikan kepada Allah SWT. Keluarga menjadi tumpuhan keberhasilan atau tidaknya dalam membentuk pendidikan karakter pada anak-anaknya. Keluarga selalu berhadapan dengan persoalan kompleks yang muncul baik dari dalam atau pun dari luar. Oleh sebab itu, sebagai orang tua wajib untuk memprediksi apabila suatu saat nanti terjadi gangguan adanya cara pembinaan karakter dalam keluarga.

Kata Kunci: Cerpen; Prinsip-Prinsip Dasar Pendidikan Karakter Dalam Keluarga
\end{abstract}

\begin{abstract}
Character education is a learning process that teaches the values of life in order to have a good moral personality. All character education processes must be well planned, implemented, and evaluated which are supported by true understanding (knowledge) and experience. This research is focused on fostering character with parents, including (1) following the
\end{abstract}


wishes and suggestions of parents in various aspects of life as long as it is not against Islamic teachings, (2) respecting and glorifying parents and thanking for their love and service, and (3) helping parents physically and materially. It is a literature study in which the researcher acts as the main instrument. The research procedure consists of three stages, namely: the planning stage, the implementation stage, and the completion stage. Fostering character in the family is something that is not easy and is impossible not to be implemented. Being kind to parents is the most important practice. For a child, in essence, all commands from parents must be obeyed, except if the command is carried out by causing shirk to Allah SWT. The family becomes the foundation of success or failure in shaping character education for their children. The family is always faced with complex problems that arise both from within or from outside. Therefore, parents have to be prepared for any disturbances that might exist during the process of building children's character in the family.

\section{Keywords: Short Stories; Basic Principles of Character Education in the Family}

\section{PENDAHULUAN}

Sastra adalah sesuatu hasil pemikiran kreatif seseorang melewati pandangan terhadap lingkungan sosial yang berada di sekitar dengan mengambil manfaatnya melalui bahasa yang indah (Gusnetti, dkk, 2015, hal. 183). Menurut Nurgiyantoro (2012, hal. 2) penyebutan istilah lain dari prosa dalam kesastraan disebut dengan fiksi (fiction), teks naratif (narrative text) atau wacana naratif (narrative discouce) dengan istilah ini mengandung maksud cerita rekaan atau cerita khayalan. Oleh sebab itu, karya fiksi menganjurkan pada sesuatu karya yang menuturkan cerita yang mengandung rekaan, khayalan, atau sesuatu cerita yang tidak tahu akan kebenarannya dan benarbenar terjadi sehingga tidaklah perlu untuk mencari kebenaran di kehidupan nyata. Sebagai karya yang bersifat khayal, fiksi mengemukakan persoalan manusia dan kemanusiaan, hidup dan kehidupan.

Cerpen (cerita pendek) adalah sebuah karya fiksi, serupa dengan novel atau pun novellet (Wahyuningtyas dkk., 2016, hal. 1330). Sedangkan menurut Yulisna (2016, hal. 73) cerpen ialah suatu wujud prosa naratif yang bersifat fiksi atau cerita karangan yang pendek yang condong padat dan langsung pada tujuannya. Keraf (2007, hal. 135136) mengungkapkan cerpen dapat digolongkan ke dalam narasi, yaitu suatu wujud wacana yang berusaha menceritakan tentang suatu peristiwa atau kejadian seakan-akan pembaca bisa melihat atau mengalami peristiwa yang berada dalam cerita tersebut. Cerpen sebagai karya fiksi dibentuk oleh unsur-unsur pembangun karya sastra yaitu unsur-unsur intrinsik meliputi alur, penokohan, latar, tema, dan amanat, dan unsur-unsur ekstrinsik meliputi nilai moral, nilai sosial, nilai budaya, dan lain-lain. Cerpen menuntut penceritaan yang serba singkat, tidak sampai pada detil-detil tidak umum yang kurang penting yang lebih mempunyai sifat memperpanjang cerita. Keunggulan cerpen yang khusus yaitu kesanggupan mengutarakan secara lebih banyak jadi, secara tersimpul di dalamnya dari sekedar apa yang diceritakan (Nurgiyantoro, 2012, hal. 11). Dalam 
cerpen banyak kita jumpai nilai-nilai kehidupan, salah satunya adalah nilai-nilai karakter.

Menurut (Surani dkk., 2016, hal. 187) pendidikan karakter dapat diartikan sebagai suatu reaksi individu yang di dalam pelaksanaan pendidikan harus berkarakter dan bertumpu dari karakter dasar manusia dari nilai moral yang berasal dari agama dan merasa mau menjalankan nilai-nilai tersebut, baik terhadap Tuhan Yang Maha Esa (YME), sesama, diri sendiri, lingkungan, atau pun kebangsaan sehingga menjad manusia yang sempurna dari segi wujud dan pengetahuannya. Sedangkan menurut Marzuki (2017, hal. 40) pendidikan karakter adalah salah satu upaya yang sangat penting dan perlu dilaksanakan oleh setiap orangtua, pendidik, atau pemimpin yang mengharapkan anak, peserta didik, atau masyarakat yang berkarakter. Membina karakter manusia sebagai generasi anak muda bisa dibangun dengan bermacam cara, yang tertanam melewati pendidikan yang dilaksanakan secara terencana, bertahap, dan berkesinambungan (Hasan, 2010, hal. 6). Prosedur dan hasil yang telah diupayakan dalam pendidikan hasilnya tidak akan nampak dalam waktu yang cepat, tetapi melalui prosedur yang sangat panjang. Melewati cara tersebut paling tidak generasi anak muda lebih mempunyai ketahanan dan mampu mencegah dari yang berpengaruh terhadap setiap persoalan dan sanggahan yang akan datang. Membina karakter tidak dapat dilaksanakan secara otodidak, namun diperlukan cara yang berkelanjutan, terstruktur, merata, dan berkelanjutan dan tidak boleh berhenti (Salim, (2013, hal. 289). Oleh sebab itu, membangun karakter anak harus dimulai sejak dini. Bermacam-macam pendidikan dan pengalaman yang dilewati anak sejak pertumbuhan pertamanya mempunyai dampak yang cukup besar terhadap penciptaan karakter diri secara sempurna (Arismantoro, 2008, hal. 124). Kurikulum pendidikan karakter harus ditumbuhkan sebegitu rupa sehingga semua aktivitas dalam proses pendidikan karakter mempunyai ketentuan dasar yang jelas dan dapat terlaksana dengan baik. Semua proses pendidikan karakter harus direncanakan, dilaksanakan, dan dievaluasi dengan baik yang didukung dengan pemahaman (ilmu) dan pengalaman yang benar.

Dalam penelitian ini, peneliti akan meneliti tentang Prinsip Dasar Pendidikan Karakter dalam Keluarga dalam Cerpen Rantai Kenangan Karya Adz Dzahabi. Alasan peneliti meneliti tentang Prinsip Dasar Pendidikan Karakter dalam Keluarga dalam Cerpen Rantai Kenangan Karya Adz Dzahabi yaitu untuk mengupas karya sastra khususnya cerpen untuk mengetahui prinsip-prinsip dasar pendidikan karakter dalam keluarga, yaitu (1) membina karakter dengan orang tua, (2) membina karakter dengan orang tua yang lebih tua, (3) membina karakter dengan orang yang lebih muda, (4) membina karakter dengan teman sebaya, dan (5) membina karakter dengan lawan jenis. Dari ke lima prinsip-prinsip dasar pendidikan karakter dalam keluarga, peneliti memfokuskan pada membina karakter dengan orang tua, meliputi (1) mengikuti keinginan dan saran kedua orang tua dalam berbagai aspek kehidupan selama tidak bertentangan dengan ajaran Islam, (2) menghormati dan memuliakan kedua orang tua serta berterima kasih atas kasih sayang dan jasa-jasa mereka, dan (3) membantu kedua orang tua secara fisik dan material. Ketiga macam kebajikan inilah yang dapat membentuk manusia berkualitas di mana pun dan kapan pun. 
Dalam penelitian ini, acuan praktis untuk prinsip-prinsip dasar pendidikan karakter Islam dalam keluarga yang digunakan adalah teori karakter yang diungkap oleh Marzuki. Teori tersebut menjelaskan tentang aturan menjalin hubungan dengan kedua orang tua agar berjalan baik khususnya bagi anak supaya menjadi pribadi yang memiliki karakter yang mulia. Pemilihan cerpen Rantai Kenangan Karya Adz Dzahabi didasarkan pertimbangan bahwa secara tersurat judul cerpen ini sesuai dengan tema yang diangkat oleh peneliti tentang prinsip-prinsip dasar pendidikan karakter dalam keluarga, yaitu membina karakter dengan orang tua, meliputi (1) mengikuti keinginan dan saran kedua orang tua dalam berbagai aspek kehidupan selama tidak bertentangan dengan ajaran Islam, (2) menghormati dan memuliakan kedua orang tua serta berterima kasih atas kasih sayang dan jasa-jasa mereka, dan (3) membantu kedua orang tua secara fisik dan material. Cerpen ini dipilih karena dapat memberi inspirasi orang lain khususnya anakanak karena berbuat baik kepada orang tua hukumnya adalah wajib dan merupakan amalan utama, menarik, dan berguna. Karya sastra yang diminati pembaca adalah karya sastra yang menarik dan bermanfaat, yang mampu membangkitkan hasrat, minat, dan keinginan untuk memperhatikan.

Artikel ini akan menyajikan tentang prinsip-prinsip dasar pendidikan karakter dalam keluarga, yaitu membina karakter dengan orang tua, meliputi (1) mengikuti keinginan dan saran kedua orang tua dalam berbagai aspek kehidupan selama tidak bertentangan dengan ajaran Islam, (2) menghormati dan memuliakan kedua orang tua serta berterima kasih atas kasih sayang dan jasa-jasa mereka, dan (3) membantu kedua orang tua secara fisik dan material dalam cerpen Rantai Kenangan Karya Karya Adz Dzahabi.

\section{METODE PENELITIAN}

Penelitian ini merupakan penelitian kajian pustaka. Hal tersebut disebabkan karena pelaksanaan penelitian ini menggunakan cerpen dan bahan pustaka sebagai sumber referensi. Adapun alasan pemilihan penelitian ini dikarenakan untuk menunjukkan hasil pendapat dari penalaran keilmuan yang mengungkapkan hasil kajian pustaka dan hasil olah pikir penelitian mengenai suatu topik masalah yang akan dikaji yaitu prinsip-prinsip dasar pendidikan karakter dalam keluarga, yaitu membina karakter dengan orang tua, meliputi (1) mengikuti keinginan dan saran kedua orang tua dalam berbagai aspek kehidupan selama tidak bertentangan dengan ajaran Islam, (2) menghormati dan memuliakan kedua orang tua serta berterima kasih atas kasih sayang dan jasa-jasa mereka, dan (3) membantu kedua orang tua secara fisik dan material.

Prosedur penelitian ini terdiri dari tiga tahap, yaitu: 1) Tahap perencanaan, 2) Tahap pelaksanaan, dan 3) Tahap penyelesaian. Teknik pengumpulan data dalam penelitian ini adalah teknik observasi teks. Analisis data menurut Miles dan Huberman (dalam Sugiyono, 2015, hal. 337) membagi tiga tahap yang dilakukan dalam analisis data, yaitu (1) pereduksian data, (2) penyajian data, dan (3) penarikan kesimpulan. Teknik pengecekan keabsahan dalam penelitian ini adalah triangulasi. Menurut Moleong (2014, hal. 330) triangulasi adalah teknik yang menyelidiki keabsahan data yang memanfaatkan sesuatu yang lain. Pengecekkan keabsahan data dilakukan dalam 
penelitian ini berupa kegiatan sebagai berikut. 1) Membaca berulang-ulang cerpen Karya Adz Dzahabi dan menelaahnya berdasarkan konsep yang ada untuk memperoleh data prinsip-prinsip dasar pendidikan karakter dalam keluarga, yaitu membina karakter dengan orang tua, meliputi (1) mengikuti keinginan dan saran kedua orang tua dalam berbagai aspek kehidupan selama tidak bertentangan dengan ajaran Islam, (2) menghormati dan memuliakan kedua orang tua serta berterima kasih atas kasih sayang dan jasa-jasa mereka, dan (3) membantu kedua orang tua secara fisik dan material berdasarkan teori Marzuki, 2) Membandingkan hasil pengumpulan data dengan teks aslinya, 3) Diadakan pengecekkan ulang dengan pengalaman peneliti setelah memahami prinsip-prinsip dasar pendidikan karakter dalam keluarga, yaitu membina karakter dengan orang tua, meliputi (1) mengikuti keinginan dan saran kedua orang tua dalam berbagai aspek kehidupan selama tidak bertentangan dengan ajaran Islam, (2) menghormati dan memuliakan kedua orang tua serta berterima kasih atas kasih sayang dan jasa-jasa mereka, dan (3) membantu kedua orang tua secara fisik dan material berdasarkan teori Marzuki, Mengadakan perbandingan antara hasil penjaringan data yang dilakukan peneliti dengan hasil diskusi teman sejawat. 5) Membicarakan dengan orang lain tentang prinsip-prinsip dasar pendidikan karakter dalam keluarga, yaitu membina karakter dengan orang tua, meliputi (1) mengikuti keinginan dan saran kedua orang tua dalam berbagai aspek kehidupan selama tidak bertentangan dengan ajaran Islam, (2) menghormati dan memuliakan kedua orang tua serta berterima kasih atas kasih sayang dan jasa-jasa mereka, dan (3) membantu kedua orang tua secara fisik dan material berdasarkan teori Marzuki yang ditemukan rekan yang kompeten atau lebih ahli.

\section{PEMBAHASAN}

\section{A. Taat dan Patuh terhadap Perintah Kedua Orang Tua}

Sebagai seorang anak wajib untuk taat dan patuh kepada kedua orang tua. Karena dengan berbuat baik kepada kedua orang tua hukumnya wajib dan merupakan amalan utama. Kehadiran orang tua untuk seorang anak merupakan pelengkap dalam keluarga. Oleh sebab itu, ikatan antara kedua orang tua dengan anak akan terjalin hubungan yang saling melengkapi satu sama lainnya dan membentuk sebuah keluarga yang harmonis. Orang tua selalu mengasihi dan menyayangi anak tidak terukur oleh batas ruang dan waktu. Mereka tidaklah pernah merasakan letih atau pun lelah dalam memberikan perhatian dan kasih sayang kepada anaknya. Yang menjadi kebutuhan untuk anakanaknya mereka kerjakan. Menurut Marzuki (2017, hal. 81) prinsip dasar pendidikan karakter dalam keluarga salah satunya membina karakter dengan orang tua yaitu mengikuti keinginan dan saran kedua orang tua dalam berbagai aspek kehidupan selama tidak bertentangan dengan ajaran Islam. Di dunia ini terdapat berbagai macam sifat yang dimiliki oleh orang tua dalam hal mendidik anak. Akan tetapi, mereka mempunyai aturan berbeda dalam mengasuh seperti, ada yang begitu mengatur, dan ada juga yang memberikan kebebasan kepada anaknya dalam hal memutuskan sesuatu. Dalam hal ini, tentunya mengakibatkan persoalan dalam mengikuti saran sendiri atau mengikuti pendapat orang tua. Jika di antara hal itu ada yang berselisih dengan ajaran Islam, tidak 
ada keharusan bagi anak untuk mencontoh mereka. Anak harus mencegah dengan cara penuh rasa hormat, dan baik. Terdapat empat data yang menunjukkan mengikuti keinginan dan saran kedua orang tua dalam berbagai aspek kehidupan selama tidak bertentangan dengan ajaran Islam dalam cerpen Rantai Kenangan Karya Adz Dzahabi yaitu diantaranya sebagai berikut.

(1) "Layla, ayo bangun sayang sudah subuh". Seberkas cahaya kuning lambat laun menerangi gelapnya penglihatan, terlihat wajah dengan senyuman indah memandangiku. Ternyata ibu membangunkanku,"iya ibu”, sahutku. Aku pun bangun untuk mandi dan sholat subuh, terlihat ibu kembali sibuk dengan urusannya.

Data (1) menunjukkan seorang anak yang taat dan patuh saat ibu membangunkan Layla untuk melaksanakan sholat subuh. Layla yang sedang tidur nyenyak telah dibangunkan oleh ibunya untuk segara mandi dan sholat subuh. Sholat merupakan kewajiban yang harus dijalani oleh seorang muslim. Setiap anggota keluarga wajib untuk selalu mengingatkan ketika anggota keluarga lalai dalam melaksanakan sholat. Karena sholat adalah amalan yang pertama yang akan diperhitungkan di akhirat kelak.

(2) Di sekolah aku berteman dengan siapa saja, aku tidak pernah mempunyai musuh.Aku selalu ingat pesan ibu untuk tidak membeda-bedakan teman.

Data (2) menunjukkan sejatinya manusia adalah makhluk sosial. Di sekolah Layla memiliki banyak teman. Dia tidak pernah membeda-bedakan dalam berteman. Ibu Layla selalu menasihati dan mengarahkan kepada Layla jika berteman sebaiknya mencari teman yang bisa saling menerima kita apa adanya dalam situasi dan kondisi apapun, dan dirasa nyaman tanpa membeda-bedakan satu dengan yang lainnya.

(3) "Layla, Laylaa, bangun sayang”. oh. Suara itu terdengar kembali, apakah ibu?pikirku. Dalam gelap kembali terdengar sayup-sayup suara yang memanggil namaku. Suara itu terdengar kembali, "Layla, ayo bangun sayang sudah subuh". Tetapi suara itu tidak lagi lembut seperti yang biasa aku dengar. Seberkas cahaya kuning lambat laun kembali menerangi gelapnya penglihatanku, terlihat wajah dengan senyuman indah memandangiku, tetapi wajah itu sudah mulai terlihat tua.Ternyata ibu membangunkanku. "iya ibu", sahutku.

Data (3) menunjukkan ibu yang sedang membangunkan Layla untuk sholat subuh. Sholat merupakan rukun Islam kedua.Sholat merupakan tiang agama dan sebagai batas pemisah antara keislaman dengan kekufuran dan kemunafikan.Sebagai orang tua tentunya memiliki kewajiban apabila anak-anaknya lupa untuk tidak sholat. Begitu pula sebagai anak pun juga akan bersikap sama apabila orang tua juga lupa untuk sholat. Membangunkan orang tidur ketika memasuki waktu sholat hukumnya wajib. 
(4) Wa'alaikumsalam hati-hati ya nak rajinlah belajar". Selalu terngiang di kepalaku kata-kata ibu di setiap pagi yang tidak pernah kulupakan.

Data (4) menunjukkan ibu sedang menasehati Layla untuk berhati-hati di jalan dan selalu rajin belajar. Orang tua menyampaikan nasehat kepada anak-anaknya karena mereka sayang dan perduli akan kehidupan anaknya supaya terhindar dari penderitaan.

\section{B. Menghormati dan Memuliakan Kedua Orang Tua}

Manusia yang dilahirkan di dunia ini memiliki tujuan untuk memperoleh kebahagiaan baik di dunia dan di akhirat. Adapun cara yang mampu memperoleh kebahagiaan tersebut adalah dengan cara menghormati dan memuliakan kedua orang tua. Apabila seorang anak menghormati dan memuliakan kedua orang tua kelak hidup akan sukses. Begitu pun sebaliknya, jika seorang anak durhaka dan menyakiti kedua orang tua, maka kelak hidupnya tidak akan bahagia dan sengsara. Kewajiban seorang anak tidaklah hanya sebatas menghormati dan memuliakan saja, tetapi selama kedua orang tua masih hidup atau pun sudah meninggal kewajiban anak adalah mendoakan kedua orang tua. Menghormati dan memuliakan kedua orang tua hukumnya wajib sejak kita masih kecil hingga sampai akhir hayat. Mereka sudah mengorbankan waktu untuk merawat dan membesarkan kita. Tugas sebagai orang tua tidaklah mudah, perlu adanya pengorbanan, dan harus sabar. Oleh karena itu, sebagai anak tentunya wajib untuk menghormati orang tua agar kita mendapatkan surga. Menurut Marzuki (2017, hal. 81) prinsip dasar pendidikan karakter dalam keluarga salah satunya membina karakter menghormati dan memuliakan kedua orang tua serta berterima kasih atas kasih sayang dan jasa-jasa mereka. Dalam Islam kedua orang tua memiliki kedudukan yang sangat mulia. Sebagai seorang ibu telah bersusah payah ketika mengandung dan melahirkan anak-anaknya. Begitu pula dengan seorang ayah yang rela membanting tulang untuk mencari nafkah demi keluarganya yaitu istri dan anak-anaknya. Tugas seorang ayah juga untuk menjaga dan memberikan perlindungan rasa aman kepada keluarga. Terdapat sembilan data yang menunjukkan menghormati dan memuliakan kedua orang tua serta berterima kasih atas kasih sayang dan jasa-jasa mereka dalam cerpen Rantai Kenangan Karya Adz Dzahabi yaitu diantaranya sebagai berikut.

(5) "Layla, ayo berangkat, sebentar lagi Ani datang", ujar ibu sembari memasukan bekal ke dalam tas cokelat milikku. "iya bu", jawabku pelan.

Data (5) menunjukkan sikap Layla yang menghormati ibunya yang sedang memanggilnya.Layla berbicara dengan suara lemah lembut.Berbica dengan lemah lembut kepada kedua orang tua adalah ciri-ciri anak yang sholeh, hormat, dan memuliakan kedua orang tua.Kita tidak boleh berbicara kasar apalagi menyakitkan.Pagi itu Layla sedang mempersiapkan diri untuk pergi ke sekolah. Setiap harinya Layla berangkat sekolah bersama sahabatnya yaitu Ani. Ibu sedang memanggil Layla untuk segera mempersiapkan diri karena sebentar lagi Ani akan menjemputnya. Layla pun dengan santun dan merendahkan nada suara menjawab panggilan ibunya. Berkomunikasi dengan orang tua harus bersuara lebih rendah dari suara orang tua. 
(6) "Ibu, Layla berangkat dulu ya Assalamu'alaikum", ucapku dengan bersalaman dengan ibu dan mencium pipi ibu. Ibu pun menjawab dengan membalas ciuman di pipi ku, "iya Layla.

Data (6) menunjukkan sikap sopan santun Layla terhadap ibunya pada saat berangkat ke sekolah dengan mengucapkan salam sambil berjabat tangan dan mencium pipi ibunya. Bersikap lemah lembut kepada kedua orang tidak hanya dalam hal ucapan tetapi sikap dan perbuatan juga harus sopan santun.

(7) Ketika di rumah aku selalu membantu ibu, aku tidak ingin ibu sakit karena bekerja sendirian.Setiap sore aku dan ibu pergi ke masjid, ibu adalah seorang guru mengaji. Ibu selalu ramah kepada semua murid-muridnya, tidak pernah sekalipun aku melihat ibu marah kepada teman-temanku bahkan kepadaku.

Data (7) menunjukkan Layla yang selalu membantu pekerjaan ibunya di rumah karena dia tidak ingin ibunya sakit karena kelelahan.Selain mengurus pekerjaan rumah, ibu Lyla adalah seorang guru ngaji yang setiap sorenya mengajari santri-santri di masjid.Tanpa kita sadari tugas seorang ibu dalam keluarga sangatlah besar.Tidak hanya sekedar merawat anak, tapi mereka memiliki tugas lainnya yaitu mengurus pekerjaan rumah tangga.Sebagai anak yang berbakti kita harus membantu meringankan tugas ibu dengan cara mengerjakan pekerjaan rumah tangga supaya tugas yang berat akan terasa ringan jika bersama-sama saling membantu.

(8) Lima tahun sudah berlalu.Aku duduk di pinggir tempat tidur sembari memperhatikan raut wajah wanita yang masih tertidur. Ya, Itulah ibuku, wajahnya sudah penuh dengan kerutan tetapi senyumnya masih saja terlihat manis dari pertama aku melihatnya. Aku pun berbaring di samping ibu untuk beristirahat. Dalam perjalanan menuju fatamorgana kupegang tangan ibu, lalu sejenak melirik tirai masa depan. Kelak jika aku mempunyai anak, aku ingin disayangi layaknya aku menyayangi ibu.

Data (8) menunjukkan sikap Layla terhadap ibunya yang begitu dia sayangi dengan memegang tangan ibu yang sedang tidur.Sejak kecil Layla di rawat oleh ibunya dengan penuh kasih sayang dan penuh kesabaran. Kini ibunya sudah mulai tua.Sebagai seorang anak sudah menjadi kewajiban kita untuk memuliakan ibu.Karena itu surga berada di telapak kaki ibu.Ibu yang sudah melahirkan kita ke dunia, tenaga dan waktunya tercurahkan untuk merawat dan mendidik anaknya.

(9) "Bunda, bunda kita sudah sampai". Suara-suara itu selalu saja muncul di dalam kegelapan.Aku kenal suara ini.Ini suara Aisyah anakku. "Bunda". Suara Aisyah terdengar lagi, tetapi kali ini tubuhku diselimuti hawa panas yang menyejukkan. 
Data (9) menunjukkan terdengar suara Aisyah yang sedang memanggil ibunya dengan sebutan Bunda.Panggilan Bunda menunjukkan rasa hormat anak kepada ibunya.Islam mengajarkan untuk berbicara dengan kedua orang tua dengan ucapan yang mengandung penghormatan.

(10) Hari ini aku merasakan pengorbanan ayah dan ibu dalam membesarkanku hingga aku akhirnya menjadi seorang ibu yang merasakan kebahagiaan.Aku pun kembali menyadari selama ini ayah dan ibu telah menjadi pahlawan dalam hidupku yang senantiasa berjuang serta berdoa untuk masa depanku. Perjuangan orangtua tidak akan mampu dibalas oleh anak-anaknya. Masih ingin rasanya aku membahagiakan kedua orangtuaku, tetapi takdir dari Allah harus kuimani.Aku bahagia memiliki orangtua seperti ayah dan ibu.

Data (10) menunjukkan keinginan Layla untuk membahagiakan kedua orang tuanya yang telah berjuang membesarkan, dan menyekolahkan hingga menjadi orang sukses.Sebagai anak sepatutnya kita harus berusaha membahagiakan kedua orang tua selama mereka masih ada. Jasa kedua orang tua tidak akan bisa digantikan oleh apapun. Dengan sikap menghormati, memuliakan, menyayangi, dan mendoakan kedua orang tua Layla sudah menunjukkan kebaktiannya kepada Ibu dan Ayahnya. Meskipun Ayahnya sudah tidak ada lagi di dunia ini.

(11)Fatamorgana masih menyatu dengan kenyataan, terdengar kembali suara yang berbicara kepadaku. "Aisyah, sayang bunda".

Data (11) menunjukkan rasa sayang Aisyah kepada Bundanya. Tidak hanya kedua orang tua yang bisa menunjukkan rasa sayangnya, seorang anak pun juga bisa menyayangi kedua orang tuanya.Rasa sayang Aisyah kepada bundanya ditunjukkan dengan mengungkapkan secara langsung.

(12) Tidak terasa air mata jatuh dari kedua mataku.Aku hanya bisa terdiam menyimpan semua kenangan di hatiku. ("Hanya orang tua, orang yang benarbenar tulus mencintaimu dan mendoakan kebaikan tanpa mengharapkan apapun dari dirimu")

Data (12) menunjukkan rasa rindu Layla kepada kedua orang tuanya yang telah tiada.Layla merindukan kehadiran mereka yang selalu berada disampingnya, mencintai dan mendoakannya. Di mata Layla kedua orang tuanya merupakan sosok pahlawan tanpa tanda jasa.Mereka merelakan apapun untuk anaknya tanpa meminta balasan atau pun imbalan. Layla menyadari tidak akan melupakan pengorbanan kedua orang tuanya. Dia hanya bisa mendoakan agar Allah menerima di sisi-Nya.

\section{Membantu Kedua Orang Tua secara Fisik dan Material}


Berbuat baik kepada kedua orang tua sangatlah dianjurkan. Sebagai orang tua tidak hanya memiliki tanggung jawab merawat, dan mendidik anak. Seorang ayah memiliki kewajiban untuk mencari nafkah dalam memenuhi kebutuhan hidup keluarganya. Sedangkan ibu memiliki tugas yang sama beratnya mengurus rumah tangga dan merawat anak-anaknya. Sebagai anak tentunya harus meringankan beban kedua orang tua dengan membantu meringankan tugas mereka secara fisik dan material, ini adalah salah satu bukti bakti kita kepada kedua orang tua. Anak berkewajiban membantu memberikan nafkah kepada kedua orang tua apabila mereka dalam kondisi tidak mampu untuk bekerja sehingga tidak lagi mempunyai penghasilan guna untuk mencukupi kebutuhan sehari-hari. Harta yang dimiliki oleh anak pada dasarnya adalah milik kedua orang tua. Oleh karena itu, Islam mengajarkan untuk menyisihkan sebagian harta untuk kedua orang tua guna sebagai tanda bukti seorang anak yang berbakti kepada kedua orang tua. Kewajiban dalam membantu kedua orang tua secara fisik dan materi ini teruntuk anak laki-laki atau pun anak perempuan. Menurut Marzuki (2017, hal. 81) prinsip dasar pendidikan karakter dalam keluarga salah satunya membina karakter dengan orang tua membantu secara fisik dan material. Terdapat dua data yang menunjukkan membantu kedua orang tua secara fisik dan material dalam cerpen Rantai Kenangan Karya Adz Dzahabi yaitu diantaranya sebagai berikut.

(13) Tetapi sekarang aku tahu pekerjaan ayah ternyata sangat berat untuk menghidupi aku dan ibu hingga akhirnya ayah jatuh sakit karena tidak sanggup lagi untuk bekerja. Aku harus belajar dengan rajin, agar aku bisa membahagiakan ibu.Itulah mimpi yang ada di kepalaku. Di sekolah aku tidak pernah mendapatkan peringkat tiga besar, tetapi aku selalu masuk peringkat lima besar.

Data (13) menunjukkan cara Layla membahagiakan kedua orang tua dengan cara meraih juara kelas. Sebagai orang tua selalu menasehati anaknya untuk selalu rajin belajar. Mereka ingin melihat anaknya sukses, menjadi orang yang berguna bagi dirinya, bagi kedua orang tua, dan berguna untuk orang lain. Kesuksesan seorang anak tidak di ukur oleh seberapa banyak harta yang diberikan orang tua kepada anak, tapi kesuksesan seorang anak tidak terlepas dari doa kedua orang tua dan dari hasil kerja kerasnya. Usaha Layla tidak pernah sia-sia. Dia selalu giat belajar untuk mendapatkan juara kelas yaitu masuk pada peringkat ke lima.

(14) Aku teringat, hari ini sangat bersejarah di dalam hidupku. Aku akhirnya berhasil meraih gelar Sarjana, tetapi yang lebih membuatku bahagia bulan depan aku sudah mulai bekerja di perusahaan besar sebagai Konsultan Arsitek, sesuai dengan jurusan yang aku geluti yaitu Teknik Arsitektur. Tidak hanya itu, kami juga akan pindah ke rumah baru yang diberikan oleh perusahaan untukku. Saat ini benar-benar segala rasa bercampur di dalam jiwaku, ibu tidak perlu lagi capek-capek berjualan untuk membiayai kebutuhan sehari-hari, ibu tidak perlu lagi bangun jam tiga subuh untuk 
menyiapkan jualannya walaupun ibu selalu bilang hanya untuk sholat tahajud, tetapi aku tahu semua itu adalah wujud ketabahan ibu dalam menghadapi cobaan hidup. Setidaknya sekarang aku sudah bisa memberikan kepada ibu kenyamanan beristirahat.

Data (14) menunjukkan usaha kerja keras membuahkan hasil. Dia sudah lulus kuliah dan berhasil meraih gelar sarjana Teknik Arsitektur. Setelah lulus kuliah, Layla langsung diterima bekerja di salah satu perusahaan besar sebagai Konsultan Arsitek. Kesuksesan Layla ini berkat doa kedua orang tua dan usaha kerja keras orang tua setiap hari bekerja demi membiayai kuliah Layla. Walaupun harta kedua orang tua habis untuk membiayai kebutuhan kuliah, mereka tidak pernah meminta hartanya dikembalikan. Kedua orang tua hanya ingin melihat anaknya sukses di dunia dan di akhirat. Kesuksesan Layla ini membuahkan hasil, dia mendapatkan tempat tinggal dari perusahaan tempat dia bekerja. Layla langsung membawa ibunya ke rumah barunya. Segala aktivitas yang pernah ibu lakukan kini Layla yang mengerjakan.

\section{KESIMPULAN}

Terdapat prinsip-prinsip dasar pendidikan karakter dalam keluarga salah satunya adalah membina karakter dengan orang tua sebagai berikut. Pertama. Terdapat empat data mengikuti keinginan dan saran kedua orang tua dalam berbagai aspek kehidupan selama tidak bertentangan dengan ajaran Islam. Kedua. Terdapat sembilan data yang menunjukkan menghormati dan memuliakan kedua orang tua serta berterima kasih atas kasih sayang dan jasa-jasa mereka. Ketiga. Terdapat dua data yang menunjukkan membantu kedua orang tua secara fisik dan material. Membina karakter dalam keluarga merupakan suatu hal yang tidak mudah dan tidaklah mungkin untuk tidak dilaksanakan. Keluarga menjadi tumpuhan keberhasilan atau tidaknya dalam membentuk pendidikan karakter pada anak-anaknya. Keluarga selalu berhadapan dengan persoalan kompleks yang muncul baik dari dalam atau pun dari luar. Oleh sebab itu, sebagai orang tua wajib untuk memprediksi apabila suatu saat nanti terjadi gangguan adanya cara pembinaan karakter dalam keluarga.

\section{DAFTAR RUJUKAN}

Arismantoro. (2008). Tinjauan Berbagai Aspek Character Building; Bagaimana Mendidik Anak Berkarakter. Yogyakarta : Tiara Wacana.

Dzahabi, A. (2019). Rantai Kenangan. Komunitas Penulis Cerpen Indonesia, Kumpulan Cerpen Karya Anak Bangsa.

Gusnetti., dkk. (2015). Struktur Dan Nilai-Nilai Pendidikan Dalam Cerita Rakyat Kabupaten Tanah Datar Provinsi Sumatera Barat. Jurnal Gramatika, Vl.i2 (183-192).

Hasan. (2010). Pengembangan Pendidikan Budaya dan Karakter Bangsa. Jakarta: Litbang Puskur. 
Keraf, G. (2007). Argumentasi dan Narasi. Jakarta: Gramedia Pustaka Utama.

Marzuki. (2017). Pendidikan Karakter Islam. Jakarta: Amzah.

Maksudin. (2013). Pendidikan Karakter Non Dikotomik. Yogyakarta : Pustaka Pelajar.

Miles, M.B \& Amichael H. (2007). Analisis Data Kualitatif Buku Sumber tentang Metode-Metode Baru. Terjemahan Tjetjep Rohendi Rohisi. Jakarta: Universitas Indonesia.

Moleong, L.J. (2014). Metodologi Penelitian Kualitatif. Bandung: Remaja Rosdakarya.

Nurgiyantoro, B. (2012). Teori Pengkajian Fiksi. Yogyakarta: Gadjah Mada University Press.

Surani, Bambang S., \& Sabar N. (2016). Pengelolaan Pendidikan Karakter Bangsa Berbasis Budaya Jawa Di TK Negeri Pembina Surakarta. Jurnal Managemen Pendidikan, Vol. 11, No. 2, Juli 2016.

Sugiyono. (2015). Metode Penelitian Kuantitatif, Kualitatif dan R\&D. Bandung: Alfabeta.

Salim, M.H. (2013). Pendidikan Agama Dalam Keluarga; Revitalisasi Peran Keluarga Dalam Membangun Generasi Bangsa Yang Berkarakter. Yogyakarta : ArRuzz Media.

Wahyuningtyas, R.N., Maryaeni, \& Roekhan. (2016). Pengembangan Bahan Ajar Menulis Cerpen Dengan Konversi Teks Untuk Siswa Kelas VII SMP. Jurnal Pendidikan, Vol. 1, No. 7, Bln Juli, Thn 2016, Hal 1330-1336.

Yulisna, R. (2016). Kontribusi Kemampuan Memahami cerpen Terhadap Keterampilan Menulis Cerpen Siswa Kelas XI SMA Negeri 4 Padang. Jurnal Gramatika, Vol 2, No 2 (2016). 